\title{
The locals and their new university - A case study of social innovation
}

\author{
KATALIN R FORRAY ${ }^{1 *}$ (1) and TAMÁS KOZMA ${ }^{2}$
}

\author{
${ }^{1}$ University of Pécs, Ifjúság útja 6, H-7624 Pécs, Hungary \\ ${ }^{2}$ Institute of Educational and Cultural Rch, Faculty of Arts, University of Debrecen, P.O.Box 17, H-4010, \\ Debrecen, Hungary
}

\section{RESEARCH PAPER}

Received: June 29, 2020 • Accepted: October 12, 2020

Published online: April 20, 2021

(C) 2021 The Author(s)

\begin{abstract}
What happens, if a university moves to a town that never had a higher education institution previously? What is the impact of this development both on the community and the institution? The aim of this paper is to answer this question. The authors use the concept of 'social innovation' for understanding the developments. An institute may initiate, organise and coordinate all kinds of learning that takes place in a given community (Bradford, 2003). To do so, the institute may have to change its missions (not only its third, but also its first, second and third ones. These developments could be interpreted as a 'social innovation' during which the local economy and society was challenged and they looked for new responses. As suggested in the 'social innovation' literature the main research method was participatory research, combined with structured and semi-structured interviews, story-telling and narrative analyses. As a result, three interest groups could be described with various requirements different demands toward the university; while the university had to modify its structure, curriculum and communications. The main lesson to learn is that 'social innovation' as a frame of interpretation can be used to understand the developmental processes that occurred between the locals and a new university.
\end{abstract}

\section{KEYWORDS}

higher education policy, community development, social innovation

\footnotetext{
*Corresponding author. E-mail: forray@iif.hu
} 


\section{INTRODUCTION}

The institution presented in this study was established in a dynamically developing region of Hungary where there was no independent higher education prior to 1990. Numerous institutions had outsourced departments here, and for a long time, they seemed to satisfy the needs of the population. However, the local government that took office in the 1989-90 free elections decided it was necessary to develop local higher education. A new state-funded university or college was out of the question in the early nineties. Therefore, a new municipal institution-a so-called community college-was established.

After years of dynamic improvement, party politics induced tensions between the leaders and the founders/maintainers of the institution, bringing developments to a halt. In the 2000s, these tensions and organisational struggles became so severe that the college broke away from its sustainer and became a private institution. Since the problems were not resolved, it was decided to move the college's main campus after 2010. By that time, the university had already had outsourced departments - among others, for example, in Budapest - all they had to take care of was the location of their headquarters. This is how the college evolved into a local university by the time of our study.

This is how social innovations begin. We know from previous research (Kozma, 2019; Markus \& Kozma, 2019) that innovation is a novel response to a social challenge. The whole community faces a challenge and the response requires new knowledge, tools and ideas that the community can respond to. Herein, all of these elements are present. Therefore, we began to study the interplay of the town and the university as a new case of social innovation.

\section{Higher education and social innovation}

What is social innovation? While innovation is an economic concept that is used quite unequivocally in economics (Polónyi, 2018), social innovation is primarily a concept of social science. The former is linked to economic changes, while the latter-whether dependent or independent of economic changes-denotes social transformations.

Social innovation has long been known in social sciences (Westley, Mcgowan, \& Tjörnbo, 2016: 1-16), but it has only become a fashionable concept since the early 2000s (Mulgan, Tucker, Ali, \& Sanders, 2007; Phills, Deiglmeier, \& Miller, 2008; Pol \& Ville, 2009). In the mid2000s, it appeared and began its conquest in regional research (Gál \& Búzás, 2005; Benneworth, Pinheiro \& Karlsen, 2017; Nemes \& Varga, 2014; Szörényiné Kukorelli, 2015). Today, the concept refers to those changes that are problem-oriented, and community-based (Bradford, 2003). These changes are defined by locality, initiated from beneath, require new forms of knowledge and their impact determines the future of a community (Moulaert, Mccallum, Melomood, \& Hamdouch, 2013; Moulaert \& Maccallum, 2019).

Some (Moulaert \& Maccallum, 2019: 113-116) talk about the ethics of social innovation, which means that innovation is 'social' when it serves social improvement. Thus, social innovation is the locality's opposition to globalisation, small communities' opposition to international forces, the protection of public property from privatisation, and the protection of social equality (but at least fairness) from unequal power-sharing forced by the strengthening market economy. We do not necessarily identify with this kind of 'ethics' of social innovation - though we admit that we are attracted to it. 
Getting acquainted with social innovations. The 'joint problematisation approach', the socalled JPA model (Moulaert \& Maccallum, 2019), presents the problems that bring social innovation to life. According to the JPA model, the problem must be identified holistically - that is, in its full social context - and pragmatically in terms of real challenges rather than principles. According to the authors (ibid 92-100), action research is a typical way of learning about social innovations. We are hesitant to apply action research because it cannot be repeated and because it tends to initiate movements that we believe a social researcher should refrain from. We prefer to write case studies based on narratives. Narratives are raw materials that can be collected relatively easily through interviews, and when confronted with each other, the scene of innovation, its factors, aspirations and tools can be clearly defined (Hyvarinnen, 2012). Most importantly, we collect and analyse stories through which the peculiarities of social innovation are gradually drawn, determined by the time and place in which the researcher carries out his or her research.

The role of the university in the ecosystem of social innovation. The role of the university in social innovation is not independent of its third mission (Hrubos, 2012; Sitku, 2019). The models used to explain the third mission (triple, quaternary and quintet spiral models) are not only used to analyse the university, but to help us understand innovation (Polónyi, 2010). Because the university (in the triple and quadruple spiral models) is a key to innovations, these models - which were originally used to explain innovation-are used to examine the university itself (Benneworth \& Cunha, 2015).

Based on the cases of nine universities, the EUA (European University Association) has recently published an interesting report on the transforming role of universities (Reichert, 2019). They do not simply convey new knowledge to those who have been challenged at a community level but manage the application of knowledge to solve the problem and the renewed learning constraints. This report affirms the changes that have resulted in the social role of universities, a changed audience and globalising university policies. Some of the interest groups of the university have been devalued and others revalued; and it has transformed the traditional organisation of universities (in which the Bologna Process plays a role, too, cf. Kozma \& Rébay, 2008).

The research and support of innovation has been transferred from the economy to the field of society since the mid-2000s, and it gave a new function to universities which were seeking their roles in the society. They found themselves in a 'spiral of innovation' in which there was an interaction between the economy, politics, society and environment.

To what extent is the cooperation and confrontation of the town and the university a social innovation? What lessons can be learned from this case to higher education as an actor in social innovation?

\section{Notes on method}

As a starting point, we used the relevant volume from Hungary's county manuals (Kővári, 1999). As an introductory orientation, we processed several documents that helped to know the terrain in detail (the collected documents can be read on requests in the authors' collection.). For statistical data of the Town, see the Database of Hungarian Settlements. We used the institution's website for the University's statistical data (www.kodolanyi.hu).

We visited the Town five times (between 2018 and 2020). We conducted interviews with the leaders of both the Town and the University. We also visited all the university campuses to conduct a field study between 2017 and 2020. The field studies' results were recorded in a 
protocol, which can also be viewed in the authors' collection upon requests. We conducted 22 interviews, the summaries of which can also be viewed in the authors' collection. Some of the interviews (12 of them) were structured, and another six were semi-structured. Interviewees were selected using the snowball method, i.e. as mentioned by the previous interviewees. They were from University leaders (rector, deputy rector, rector's advisor, campus directors, university institute heads, office manager). We conducted eight interviews with the Town's administrative and economic leaders, leaders of cultural and educational institutions, local and national policy leaders, and opinion leaders.

Following the JPA model (Moulaert \& Maccallum, 2019: 103-105), a holistic approach was used. As we examined events, social movements and decisions, we were curious about the participants' narratives (storytelling, cf. HYVARINEN, ibid). Actors were characterised by how they appeared and behaved in the stories. Individual groups of actors and their behaviours were drawn with 'research empathy'.

Here we note our reservations about quantitative policy research. Anyone who wants to examine the processes, changes and transformations of society quantitatively can only grasp the circumstances. The transformation of society can be examined holistically, with research empathies already mentioned.

\section{The town}

Its location in the city network. It is a small town of approximately thirty thousand inhabitants (hereinafter referred to as 'the Town'), which is primarily involved in agriculture but has also experienced a rise in industrial activity. It was granted the city rank for about seventy years (Köváry, 1999). The other towns are not much bigger in the county - some are even smaller. However, they have developed their own image: one is an administrative centre (which has grown to be the largest), another is an educational centre, and a third is a cultural centre. The connection between the Town and other members of the city network is unclear. Although the administrative classification is very important, its agriculture links the Town traditionally to its surrounding area. Social, cultural and political ties tangibly connect the Town to the nearby large city rather than to its county centre. Here, the attraction of the multi-county region's centre meets the attraction of the county administration.

The international railway line crosses the county but does not run across the Town; it only has a wing line. A secondary national road connects it to the county centre and the abovementioned regional centre. As it only has a by-line, the public road is obviously more important to the Town concerning its economic relations.

Economy. Though local industry has become increasingly significant in the last three decades, the Town has been defined by agriculture since its establishment. This industry is dominated by some influential multinational companies to which some three thousand small and mediumsized companies are connected. The visitors have the impression that the Town is one of the industrial centres of the county. This impression stems from the transformation that followed the regime change. There was massive privatisation, which clearly stemmed from internationalisation, especially in those three companies which were dominant before the regime change. With the emergence of a market economy and with the appearance of international capital, they entered the international (primarily the European) scene. 
Industrialisation started about seventy years ago, following World War II and the consecutive changes in power after that. The politically motivated localisation of the Town's industry considered two aspects: the potential unemployment of the Town due to the unequal distribution of agricultural lands, and the well-known left-wing commitment of the population. The Rákosi system intended to reaffirm and reward this left-wing commitment with industrialisation.

Society. The image of the Town still reflects the intertwined and layered social and economic changes and the fact that these changes were not only partly caused by internal forces but were mostly initiated by external interventions. The industrial park mirrors the transformation of the economy, while the inner part of the city mirrors the layers of social transformation. In the traditional sense, the Town does not have a main square, but has spaces of various functions and histories instead, which are defined partly by the buildings of the state administration (town hall), partly by the buildings of historical and cultural traditions (the old temple and its surroundings), and partly by the buildings of the former farming society. Today, the administrative centre is truly impressive - the others partly have classical value and partly evoke urban nostalgia. Social transformation is a longer process than current economic changes, as it is embedded in the Town's collective memory, and even in the Town's architecture.

After the change of regime, the two former collective farms became enterprises or were privatised by former members and who later sold the land. The people who divested of their property and work, whether as workers or as citizens, had become landless. The members of the Town were only bound by social and cultural values (family, tradition and memories), but not by economic rationality. The fate of many other small and medium-sized Hungarian towns finally reached the town following a wave of emigration (wherein many people left the Town). This is one of the most common topics in public discourse and one of the most common references when it comes to innovations.

While the Town's population is slowly decreasing, the dynamically developing industry-which is oriented to new markets and backed up by international capital-is facing a shortage of labour. Some town leaders explain that any locals who are not employed are practically unemployable. Others, especially industrial leaders, are more practical. Foreign migrant workers have also appeared in the city. For big companies, it is cost-effective to employ even weekly-commuting foreign workers, and the Town is a partner in that even in the cost of providing housing. (An independent workers' accommodation was built for the migrant workers, which is rare even on a national level). This contradiction - on the one hand, thousands of public workers, and on the other hand, foreign guest workers stationed on new workers' accommodation - is not more scandalous just because it is not well-known - but still, it is one of the hidden conflicts of the Town's society.

Image construction. Some people are trying to slow down and ease the Town's depopulationwhich is accompanied by the increasing influx of migrant workers-by preserving traditional values. This preservation of traditional values is expressed the most emphatically in the search for a defining image; an activity organised and controlled by the local government. (As our previous research has shown, cf. Social Innovation and Community Learning 2019, at present this type of social innovation is quite widespread in Hungary). For the past one and a half decades, they have been trying to establish outstanding institutions. They have also tried to find those people who would support one or the other idea because they recognised their own interests and found their identities in them. A modernised and internationalised industry is one 
possible image of the Town, especially when it is expected to provide moral and financial support. Another image is based on the local history, the cultural heritage and the sense of identity stemming from it, which would honor the Town's agricultural heritage.

A third image could be the traditional left-wing position of the Town. Its representatives repeatedly find themselves in political conflicts with those who would rather rely on the origin story of the Town. A fourth option would be tourism and the local spa, whose history goes back to pre-World War times and is interwoven with the late citizenry. The 'educational town' has also emerged in discussions with Town leaders as a potential image-forming element.

The schools. Schools are a sensitive issue concerning the meeting of the Town and University. The Town had no higher education until very recently, and an 'educational town' cannot exist without higher education today. In this study, we've encountered a kind of negative image building: our interviewing partners emphasised that, compared to other towns in the county, it is the only one which still does not have higher education.

Currently, no city has state-funded higher education in the county: all higher educational institutions have come under ecclesiastical control over the past decade. Few people have noticed this, and it is still neither the subject of public political debates nor of urban political discussions. In this situation, the Town faces a great dilemma. Should the Town try to bring state-funded higher education to the settlement, or should the Town accept that there will be an ecclesiastical institution of higher education (if there will be one at all)?

In fact, as the population has been decreasing, the number of students attending the county's higher education is declining, too (due to the development of public education in the mid-2000s). Thus, it is now possibly too late to establish a higher educational institution in the Town. However, a prospective 'educational town' wants to establish a college right now, as it could add to the town's new image. This is not the principals' or the rector's problem - theirs is to maintain or to increase the number of their students - nor is it the problem of the national education policies. This is the problem of the local, urban education policy if an urban education policy still exists.

Higher education has been tried twice before in the Town. Once, at the turn of the 1950s and 1960s, there was a major expansion of higher education in Hungary, which entailed the reorganisation of secondary vocational education institutions (technical schools) into partially higher educational institutions. In the Town, there was an agricultural vocational training which could have become a college of higher education (as a group of town governors wanted it to happen). The story has not been studied yet, though it would be exciting to do so. All that is preserved about the case is that the technical school finally moved to the neighbouring town, where it later became a college, so the Town lost the opportunity at that time.

The second attempt, which continues to this day, is related to the university of the regional centre. The institution of the regional centre (Szeged) tried to organise outsourced training in the Town. Some say this effort was a success, while others say it was a failure. Our discussion partners have always told the story of establishing a higher educational institution as though it was bound to be realised (although everyone admitted that previous attempts had failed).

In the absence of higher education, the gymnasium is at the top of the imaginary 'educational town', where most of the political, cultural and economic leaders of the local community studied, just as those who from time to time tried to organise university programmes in the Town. The gymnasium undoubtedly exceeds the quality of other schools of the Town, and it enjoys the support and open or covert allowances of the respective leaders. The gymnasium itself 
can be a telling story full of attempts to adapt to current political changes, with occasionally rewritten histories of the institution - or with the shifts of emphasis, from the founder to the eponym, from nationalisation to reprivatisation. The gymnasium's principal considers his institution his most precious achievement in his life, and to ensure his institution's prospects, he joined into outsourced education and national research.

Other schools-including vocational training institutions-understandably do not take their cues from the labour market, but rather from the above-mentioned gymnasium. Open and covert government allowances currently override what the participants of the economy can do to provide education, even though an army of professionals emphasises the relationship between economy and education. Economic participants-including the three multinational companies-tend to organise the necessary training on their own and send the appropriate employees for training abroad, but within their own international corporation. These trainings are complicated, and we have not been able to review them yet. What is certain is that corporate training is clearly distinct from the training offered by the Town's schools. The available training in the Town is more school-specific and, as such, tends to consider the gymnasium as a model rather than the needs of the labour market. The realignment of the vocational training that is in progress (2018-2020) does not help (or only negligibly helps) (cf. Forray, 2019).

Those who would like to see the Town as an 'educational town' can be divided into three groups. The first group - the 'traditionalists' (whether its members think about higher education or not) - builds on the gymnasium. Many would rather not think about it, even if they started the conversation with higher education. In the end, we came to the conclusion that higher education should not only be organised by those who desire and know how to develop it, but that it should remain the concern of the industry, should primarily concern adults, and should in no way diminish the gymnasium's reputation. The second group, called 'prestige seekers' emphasised the Town's prestige and said that if higher education is everywhere, the Town could not remain without it either. They were originally not from the Town, but they moved there later. But they were by no means a student of the gymnasium, at best they studied in another school of the Town. A third group, the 'market developers', however, reflected on the needs of the economy. Among other things, they reflected on the contradiction between the appearance of unskilled public work-scheme labourers and the arrival of migrant workers who commute to or settled in the Town. They are closest to the Town's economic sphere, usually independent of the administration and party politics. However, they are not industrial managers, as one might think; they were only mentioned even in conversations.

Thus, this dividedness confronted the University when it appeared in the Town. The question is: who did the institution face when moved to the Town, and how did it manage to get along with the various interest groups?

\section{The University}

Changing the location of the main campus. The headquarters of an institution always holds both practical and symbolic significance (Kozma, 2004). Traditional higher educational institutions have the same name as their headquarters, even if there are outsourced departments, and the settlements that serve as the locations for the institutions usually insist on their higher education. The history of the institution (hereinafter referred to as the University) presented in the introduction shows how this tradition came to an end. By moving away from where it was 
established, the University tore up its roots. By moving to the Town, the institution took a huge risk. Moving from its original location to a small town is a decision that is typical of the University's leaders and maintainers -so it is definitely an extraordinary institution.

The reasons behind the University's move from its original location have not been fully clarified by our investigation. Our interviewees referred only vaguely to political conflicts and financial crises. They have almost completely moved, with only one office being maintained at their original location. The demand - that the University had previously fulfilled for the residents of its location - which had originally brought the University to life - was immediately met by institutions in Budapest and the countryside. In short, there was no way back.

There are clearer explanations for why the University moved to the Town. According to some, it had predecessors here (though the University had them elsewhere too). Twenty-five years ago, the University organised outsourced training in the Town; more precisely, the University gave its name and national recognition (accreditation) to training initiated or brought here by certain intellectuals (mainly teachers) of the Town. The Town, as mentioned before, had no higher education. The expert who originally initiated teacher training contacted the University, which then registered teacher training as an outsourced training.

Another explanation is that the Town has an advantageous tax policy, as a settlement in a stagnant region. It is financially beneficial to move, even if the University risks its image by doing so. Another question is why taxation is important for a higher education institution. The answer is that the University is a private institution; therefore, taxation is one of the most important issues concerning its expenses.

A third explanation is that those who invited the University to the Town offered significant incentives. Two of these are extremely important. One is the financial support that continues to be provided to the University even to this day. The other is the physical building, which was let for free use (previously, the local government had taken the building over from the army). The University has spectacularly renovated the building and its leaders now proudly show that it is more beautiful than its building on its original location.

Based on numerous accounts, the location change of the main campus has a symbolic significance. On the one hand, it refers to the Town, which was looking for an institution, and, on the other, points forward to the University, which changed financial backers and organisational forms in order to move to the Town.

Changing the financial backer. After all, the University has never been state-funded. The founder merely said that they were jealously guarding their independence (though it is questionable whether reliance on the 'market' is better than dependency on the state administration or not). Considering its founding, the Institution was not a private one unless we consider the former community colleges as private institutions (cf. Kozma, 2004: 78-90). It became a private institution only when the local government surrendered its maintenance. It received state funding even as a private institution because, in the 2000s, state-funded higher education places were distributed on a liberal basis, independently of the figure of the financial backer or the funder.

Thus, privatisation had several factors. One was the break-up with the former financial backer based on party-political affiliation. Another was the financial factor: state-funded higher education places were no longer distributed to the University and in the absence of these, the institution was forced to modify its training programmes as desired by the 'market' or-more 
precisely-by the consumers, the applicants. It could not represent 'missions' such as those established by traditional universities in the strong defence of their state funding. The University had to adapt, and it had already begun to adapt when the international debate on private universities and for-profit higher education reached Hungary in the mid-2000s.

The third factor of privatisation - in fact, the most important one - is the person who founded, organised and managed the University, risking his or her professional career, even his or her private life. From the analysis of social innovations, we know who (s)he is - that particular 'local hero' (also known as the 'manager of change', cf. Kozma 2003). We have seen such 'change managers' at the time of the regime change in Hungary and in several other system-changing countries where community colleges emerged (Kozma, 2005: 37-161) (The fate of these change managers is one of the unexplored areas of higher education. One reason for this can be the reserved nature of these change managers. The University had to adapt, and it had already begun to adapt when the international debate on private universities and for-profit higher education began in the early 1990s and reached Hungary (cf. Setényi, 1992).

The University, which contacted the Town, was not a traditional institution; it did not look for the privileges and protections of local-government funding, though it accepted the benefits offered. The expectations of the invitee and the inviter did not really meet; more precisely they did not meet at all and this was also reflected in careers. Those who worked for a university for decades, mostly from the group of 'prestige seekers', soon stood aside disappointedly. This worsened the University's chances of integration because it lost an important network of contacts. The University was not 'grateful' in the traditional sense of the word, as it was forced to develop a strategy in which only successful market-building could generate gratitude and generosity. The leaders of the University rather sought benefits in which other networks of connections and other groups were revalued. The University came to a non-traditional Town, although the University wasn't conventional either.

From University to enterprise. If the University had been or had wanted to remain a traditional higher education institution, the change in the main campus's location and its moving to the city probably would not have happened this way (or would not have happed at all). Today, it operates as an enterprise, fulfilling the promises made in the debate on private universities one and a half decade ago. It is true that the University operates in a relatively protected environment in which it was the first to take this step (other universities are now experimenting with alternative forms of maintenance), so the initiative has helped the University. There was and there is, however, a huge risk in that. There is no proper regulation for these institutions with new kind of maintenance, so there are no working administrational processes for them, either. The University is not only threatened by the shortage in undergraduates but by its result - liquidation as well.

For taking this risk, financial success can be the University's reward. At this stage of our investigation, we did not gain any insight into the university's management, as only its successes were reported. However, the sight that welcomes the visitor at the new main campus of the University is impressive. It seems that the University is improving. Whether it is true or not, they must believe in the well-being of their institution and demonstrate this belief publicly. They need to convince the public that the University has provided for the community it was moved to, and that it meets and satisfy the higher educational needs of the Town and its region. Institutional PR is highly valued in this form of financial maintenance. Not only must the potential undergraduates be convinced, but also competitors and even future investors. Higher 
educational PR is something new for the Town. PR activities are not far from other universities either, but here, it is innovative just like their goals, even if they seem modest - for example attracting as many students as they previously targeted, hosting university events, competing with supposed or real rivals, and so on.

In any case, rivals have already recognised the appearance of the University. For the time being, they are trying to depreciate the competition, and they are looking down on the new entrant. But well-known tricks used in competitions - seclusion and the withholding of information - are becoming more and more common. In this competition, the University does what the more vulnerable newcomer tends to do, offering partnership instead of competition, and market-sharing instead of exclusion (but only with moderate success). A monitoring study may convince researchers of how this competition is developing.

Transformation of training. The aim of the competition is to attract the Town and its region's students, whose numbers are decreasing. The most important tools to achieve this purpose are training profiles. Since there are no other institutions of higher education in the Town, a group of 'traditionalists' is trying to lead the University to a path where it can be organised smoothly, without offending the Town's traditional schools. For example, they would like to offer vocational training for adults who have already settled here, or for migrant workers who desire to settle in the Town. However, the University thinks differently. The Institution wants to create a training profile that is less related to the society-to the desirable or imaginary image of the city-but rather to its economy. It is therefore mainly seeking the support of 'market developers', including those corporate managers who would be expected to be interested in new professional training.

However, it is possible that neither the opinion-shapers of the Town nor the leaders of the University have managed to address these managers who are mentioned so often. Perhaps they are looking for them in the wrong place because even if there are managers, they do not need training outside their companies. If we think about the commuting foreign migrant workers-who are probably more valuable because they are relatively unqualified (it is easier to exploit them)-then we should be suspicious concerning the new kind of training that is tailored to satisfy the demands of the labour market. The dilemma of distinct expectations comes up again, here: the University takes the risk of offering something that the target partner is not even looking for.

International patterns provide another reference to the new training profile. One of the recurring ideas is the training of corporate IT and of IT teachers. Today, it is not yet possible to determine whether the leaders of the University really had an intuition of future needs or whether they were in the dark. However, it is now apparent that the appealing goals that were originally set and the initial results are far removed from each other. There are two possible ways out: either to change the training, or to look for the target audience somewhere else.

The third reference of the new training profile is the changing needs of students - and in this respect, the University has decades of experience. Teachers are the most reliable and most motivated potential audience available in small towns. Inspired mainly by the national education management, the Hungarian pedagogue society is a significant consumer of various postgraduate courses and training at present, and in this regard, the University has been outstanding so far. This is demonstrated by the wide range of satisfied audiences, even from varied geographical locations. In the course of our investigation, we also met people who chose courses organised by the University instead of traditional university centres and even contentedly recommended them to their colleagues. 
With the rapid and market-responsive development of its new education profile, the University, like an amoeba, is trying to crawl into and to stabilise its position in the Town through the fractures and conflicts that are present in the Town's society. It strives to be everywhere, to try everything out and make the most of it; whether we talk about short-term training, cultural events, tourism or applied research. It appears as an organisation with a varied profile that the developers of higher education recommend everyone to build-though not all institutions take such advice. Anyone who does, however, classifies this as one of the 'third missions' of his institution. This is not a third or marginal mission for the University, but a first or primal one because it is struggling for its very existence.

From an Educational Institution to a Learning Centre. In the race it has entered - partly to meet the Town's expectations and partly to keep up with its rivals - the University is gradually shifting to the most modern directions. The most striking of these is the transformation from an educational centre into a kind of learning or learning help centre. (The 'learning help centre' includes education, too - but it is much more than that: it is an activity that has a complex, overall influence on students' well-being.) This is reflected in how potential undergraduates are looked for, invited, and guided through the process of entering, staying in, and finishing their university programmes. Another example is how the Institution adapts to different student groups in space and time: the University does not only seek out and keep its students, but it also provides distance-learning programmes and assists them individually. All this is becoming more and more interrelated to technologies that support learning. If the Institution really manages to become a 'learning help centre', that is going to be a real step forward. At the moment, it seems that the University will succeed if we consider its student groups organised at home and abroad as well as its distance learning students.

Structural transformation. This alteration is extremely labour-intensive. By starting these programmes, the University took an enormous risk. Labour force is the most valuable for the University, too; however, diversified training programmes and teaching-learning procedures require the disciplined cooperation of many professionals (and many students). Info-communication technology can help, but it does not replace the teacher, even if it costs money.

The organisation, which is adapting to its environment like an amoeba, has formed a 'flat' structure. This means that the hierarchy of direction is as minimal as possible - the Rector directs the Chief Secretary; the staff of the Secretariat is involved in education as well as the Rector himself - and they try to minimise the number of the technical staff. They are able to do it partly because of the relatively low number of their full-time students and the low number of training levels offered; especially as they offer only a few in one place (they offer only undergraduate programmes in some locations and masters in others). The flat hierarchy fits in well with the training provided at many campuses. At present, the University has two other main campuses in addition to its headquarters in the Town, not to talk about the numerous places of training it offers abroad and domestically to reach certain student groups.

However, this also entails the risk of losing the hierarchy which makes the University organisation permanent and stable as an organisation. The different campuses and the journeys between them not only make the institution elusive, but also jeopardise its stability. Everything that stabilises a well-established educational institution is at stake here: timetable, term, curriculum, syllabi, textbooks and instructors. The University must face this kind of tension if it pursues the strategy it has developed so far. 
This is reflected in the interiors of the University. These spaces, like community buildings, play a central role, while the administration remains in the background and its location is only a minor issue. Getting to know several buildings of the University, the general experience was that the administration was overshadowed by meetings and student gatherings. Such a specialised spatial organisation can be seen in the so-called open office centres, modern shopping centres, editorial offices, but not in educational institutions.

The institution, which is so far from being a traditional one, risks undermining the very reasons it was originally invited and resettled by the Town. For the University, 'the prestige seekers' fought most actively, and they needed conventional, rather than innovative higher education. The University's main building, its appearances, events, invitations, events and ceremonies that are all meant to be traditional - cannot all be held in their own buildings - and the rank of their instructors, the nameplates, their academic achievements are meant to express that the institution is worthy to be called a university. The University fulfils all these with dubious results. Traditionalists believe that the conventional gymnasium that is in the Town centre represents the educational character of the Town better - even if its building is not conventional enough to live up to the traditions that are attributed to this school, - than a modern institution in the midst of its transformation, even if it is officially classified as a university. We could also say that the Town is not keeping up with the transformation of the University, but it is also possible to say that the University misunderstands what the Town expects of it.

\section{CONCLUSIONS}

There is no innovation without challenge. The most common of the many misinterpretations is that if something is new, it should be called innovation without considering whether it is organised from above or below, whether it happens only once, or whether it is a lasting change. However, innovations are only social if they provide novel responses to real social challenges. There is apparently a social problem (a town without a university) and a novel answer (a private university) in the meeting of the Town and the University - but the question is not so influential to be a social challenge, so the innovation is not really the answer. The lack of higher education seems to bother the town leaders, but it is not a challenge for everyone. So, the answer, which is the appearance of the University, is unquestionably an innovation, although it is an answer to a problem that is not important and extensive enough to be considered a social one. The importance of education for the Town must always be asserted because the local society does not seem to agree upon its importance. Thus, the emergence of the University is not rooted in a social need that it could satisfy.

The challenges that may pose a threat to the Town - to which leftist social groups might be even more sensitive than traditional (middle class) circles - is emigration, demographic risk and most recently the appearance of foreign migrant workers. The latter has not yet become a vital challenge for the Town at the time of our research, though it may easily become one in the near future. What the city leaders think about it - that foreign migrant workers will settle down, marry into the local society and within one or two generations they melt into the society and stop the outward migration - is probably naive. What is obvious is that the leading circles of the Town do not perceive these problems as challenges for the whole community - and they do not perceive the university being able to respond to these problems. 
Thus, social learning, the core of social innovation, is missed. There are many topics of common talk in the Town, but they do not include guest workers or demographic risk. Neither was the emigration of the young generation conceived as a social challenge - or, if it was, preserving traditions would seem to be a remedy. If anyone talks about the radical recession or stagnation, he/she could actually be right. Even the Town's dynamically developing industry is now becoming more isolated from the Town, since its problems have so far not been identified as a challenge to the whole community.

Will the 'educational town' successfully develop in the future? This is not only a theoretical question for those studying social innovation but also a question for professionals and politicians committed to urban development and education organisation. The answer, we hope, is yes. However, there is still a lot of persistent and purposeful work to be done, including many further research as well.

Ethics: The study procedures were carried out in accordance with the Declaration of Helsinki. The Institutional Review Board of the Institute of Educational and Cultural Research at the University of Debrecen, Hungary approved the study.

Funding: No financial support was received for this study.

Author's contribution: Tamas Kozma has prepared the theoretical frame of the study, and he took responsibility for the References. The authors had full access to all data in the study and take responsibility for the integrity of the data and the accuracy of the data analysis, study concept and design, statistical analysis, study supervision, interpretation of data.

Conflict of interest: The authors declares no conflict of interest.

\section{ACKNOWLEDGEMENTS}

This is the extended and edited version of a lecture presented at the XIX. National Conference on Education (University of Pécs, Hungary, 8-10 October 2019). (Full text is available on ResearchGate, https:/www.researchgate.net/publication/339376279) We would like to thank our local partners that they were available and told their stories. For the protection of their personal data, the sites of the case study, the organizations visited, and the background documentation are not included in this case study. However, they can be viewed in the authors' collection with the permission of the participants.

\section{ABOUT THE AUTHORS}

Katalin R. Forray, Prof. Dr (born 1942 in Mezőtúr, Hungary). Degrees: Doctor of Hungarian Academy of Sciences, Habilitation. Present position: member of the Doctoral School for Education and Society in Pécs University. Key qualifications: integration of minorities (e.g. Roma), multiculturalism, social, economic and regional factors in the institutional system of education. 
Tamas Kozma is professor emeritus (sociology of education, comparative and higher education research) at the Institute of Educational and Cultural Studies and founding president of the Center for Higher Education Research and Development, both at the University of Debrecen (Hungary). He has studied theology, history and education in Budapest (Hungary), Szeged (Hungary) and Cluj-Napoca (Romania). He has received his PhD from the University of Szeged, his C.Sc (Candidate of Sciences) and D.Sc (Doctor of Sciences) from the Hungarian Academy of the Sciences, and his habilitation from the University of Debrecen. He was the general director of the Hungarian Institute for Educational Research (Budapest) between 1990 and 2000. He has published 18 books and around 200 papers and articles (mostly in Hungarian and partly in English). His recent volume (in Hungarian) titled 'The Right Time. Education and Transition, 1988-1993' His research activities can be followed on Academia.edu and ResearchGate. Prof Kozma is-among others-the founding editor of HERJ Hungarian Educational Research Journal and president of HERA Hungarian Educational Research Association.

\section{REFERENCES}

Benneworth, P. S., \& Cunha, J. (2015). Universities' contributions to social innovation. European Journal of Innovation Management, 18(4), 500-527.

Benneworth, P. S., Pinheiro, R., \& Karlsen, J. (2017). Strategic agency and institutional change: Investigating the role of universities in regional innovation systems. Regional Studies, 54(2), 235-248.

Bradford, N. J. (2003). Creative Cities. Canada: Westwrn Ontario University.

Forray, R. K. (2019). Szervezeti innováció és szakképzés. Kultúra és Közösség, 10(1), 13-20. http://www. kulturaeskozosseg.hu/index.php?option $=$ com_content\&view $=$ article\&id $=95 \& I t e m i d=101$ (Last Visit: 10.01.2021) [Organizational innovation and vocational training, Hungarian.].

Gál, Z \& Buzás, N (Eds.), (2005). Az egyetemek szerepe a regionális innovációs hálózatokban. In Tudásmenedzsment és tudásalapú gazdaságfejlesztés (pp. 269-292), Szeged: JATE Press [The role of the universities in the regional innovation ecosystems, Hungarian].

Hrubos, I. (Ed.), (2012). Elefántcsonttoronyból világitótorony. Budapest: Aula Kiadó [From Ivory Tower to Lighthouse, Hungarian].

Hyvarinen, M. (2012) Analyzing narratives and storytelling. In The sage handbook of social research methods (pp. 447). https://books.google.hu/books?hl=hu\&lr=\&id=eTmsn2-tYtAC\&oi=fnd\&pg= PR5\&dq $=$ THE + SAGE + HANDBOOK + OF + SOCIAL+RESEARCH (Last Visit: 10.01.2021).

Kőváry, Péter (1999). Békés Megye Kézikönyve. Handbook of County Bekes, Hungarian. Szeged: CEBA Kiadó.

Kozma, T. (2003). Változások hordozói. Educatio ${ }^{\circledR}, 12(1), 65-78$ [Chnasge agents, Hungarian].

Kozma, T. (2004). Kié az egyetem? Budapest: Új Mandátum. [Who Runs the University? Hungarian].

Kozma, T. (Ed.) (2005). Kisebbségi oktatás Közép-Európában. Budapest: Új Mandátum. [MinorityEducation in Central Europe, Hungarian.].

Kozma, T. (2019). A társadalmi innováció értelmezései. Kultúra és Közösség, 10(1), 5-11. [Understanding social innovation, Hungarian.].

Kozma, T. \& Rébay, M. (Eds.), (2008). A bolognai folyamat Közép-Európában. Budapest: Új Mandátum.

[Tha Bologna Process in Central Europe, Hungarian.].

Kozma, T. (2004). Kié az egyetem? Who Runs the University? Hungarian. Budapest: Új Mandátum. 
Márkus, E., \& Kozma, T. (Eds.), (2019). Learning communities and social innovations. Debrecen: CHERD \& Debrecen University Press.

Moulaert, F, \& Maccallum, D. (2019). Advanced Introduction to Social Innovation. Cheltenham UK: Edward Elgar Publishing.

Moulaert, F., Maccallum, D. (2019). Advanced introduction to social innovation. Cheltenham: Edward Elgar Publishing.

Moulaert, F., Mccallum, D, Melomood, A. \& Hamdouch, A. (2013). The international handbook on social innovation. Cheltenham: Edward Elgar Publishing.

Mulgan, G., Tucker, S., Ali, R., \& Sanders, B. (2007). Social innovation. http://eureka.sbs.ox.ac.uk (Last Visit: 10.01.2021).

Nemes, G., \& Varga, Á. (2014). Gondolatok a vidékfejlesztésről. Educatio ${ }^{\circledR}, 21(3), 384-393$ [Some thoughts on rural development, Hungarian].

Phills, J. A., Deiglmeier, K., \& Miller, D. T. (2008). Rediscovering social innovation. Stanford Social Innovation Review, 6(4), 34-43.

Polónyi, I. (2010). Az akadémiai szféra és az innováció. [The Academia and the innovation, Hungarian] https://www.researchgate.net/publication/316669476_Az_akademiai_szfera_es_az_innovacio_-_a_ hazai_felsooktatas_es_a_gazdasagi_fejlodes (Last Visit: 10.01.2021).

Polónyi, I. (Ed.), (2018). Innováció. Educatio ${ }^{\circledR}, 27(2), 161-290$ (Special Issue) [Innovation, Hungarian].

Pol, E., \& Ville, S. (2009). Social innovation: Buzz word or enduring term? The Journal of Socio-Economics, $38(6), 878-885$.

Reichert, S. (2019). The role of universities in regional innovation ecosystems. https://eua.eu/downloads/ publications/eua\%20innovation\%20ecosystem\%20report\%202019-3-12.pdf. (Last Visit: 10.01.2021).

Setényi, J. (1992). Privatizáció, Educatio ${ }^{\circledR}, 1(2), 177-193$. [Privatisation.].

Sitku, K. (2019). Vidéki egyetemek harmadik missziós tevékenysége. Iskolakultúra, 29(8), 83-94. [The third missions of the country universities, Hungarian].

Szörényiné Kukorelli, I. (2015). Vidéki térségeink innovációt befogadó képessége. Tér és Társadalom, 29(1), 97-115. [The capacity of rural regions for innovation, Hungarian].

Westley, F., Mcgowan, K., \& Tjörnbo, O. (Eds.), (2016). The evolution of social innovation. Cheltenham: Edward Elgar Publishing.

Open Access. This is an open-access article distributed under the terms of the Creative Commons Attribution 4.0 International License (https://creativecommons.org/licenses/by/4.0/), which permits unrestricted use, distribution, and reproduction in any medium, provided the original author and source are credited, a link to the CC License is provided, and changes - if any - are indicated. (SID_1) 